\title{
Corrosion Resistance of Cr-bearing Rebar in Simulated Concrete Pore Solutions
}

\author{
Sung-Ho TAE ${ }^{1)}$ and Takumi UJIRO ${ }^{21}$ \\ 1) Sustainable Building Research Center, Hanyang University, Ansan 425-791 Korea. E-mail: jnb55@hanyang.ac.kr \\ 2) Stainless Steel Research Dept., Steel Research Laboratory, JFE Steel Corporation, Chiba 260-0835 Japan.
}

(Received on March 16, 2007; accepted on June 18, 2007)

\begin{abstract}
As a fundamental study on the Cr-bearing rebar with the necessary corrosion resistance for use in steel reinforced concrete structures under corrosive environments This study was investigated to corrosion resistance of Cr-bearing rebars in simulated concrete pore solutions with content of chloride ion. The rebars were made from steels containing $\mathrm{Cr}$ from 0 to $16 \%$. SUS304 stainless steel and SD345 carbon steel were also used. Simulated concrete pore solutions were saturated with $\mathrm{Ca}(\mathrm{OH})_{2}$, containing $0.27 \%, 1.07 \%$ and $21.4 \% \mathrm{NaCl}$. The $\mathrm{pH}$ value of the solutions was adjusted to 12.5, 11, 10 and 9 by $\mathrm{HCl}$. Pitting potential and impedance, corrosion morphology of the steels in the solutions were investigated.

The results of the study showed that the corrosion resistance increased as the $\mathrm{Cr}$ content increased regardless of the content of chloride ions, and that the $\mathrm{Cr}$-bearing rebars with a $\mathrm{Cr}$ content of $5 \mathrm{C} \%$ and $9 \%$ showed good corrosion resistance in $1.07 \% \mathrm{NaCl}$ solutions at $\mathrm{pH} 12.5$ and $\mathrm{pH} 10$, respectively. Cr-bearing rebar with a $\mathrm{Cr}$ content of $16 \%$ showed as good corrosion resistance as SUS304 steel even in $21.4 \% \mathrm{NaCl}$ solutions at $\mathrm{pH} 10$.
\end{abstract}

KEY WORDS: Cr-bearing rebar; corrosion resistance; pitting potential; impedance; corrosion morphology.

\section{Introduction}

The corrosion of RC structures demonstrates very complicated forms of deterioration intermingled together but all pointing to a decrease in the durability of RC structures by the corrosion of the reinforcing bars. ${ }^{1,2)}$ For this reason, many studies have been performed to discover the best method of preventing corrosion in reinforcing bars. However, most of them have been disproportionately concentrated on the improvement of concrete quality such as the increase in concrete cover thickness, optimization of waterto-cement ratio or the addition of corrosion resistant materials. In Japan, epoxy-coating rebars are the only technology of rebars to prevent the corrosion. The epoxy coating rebars, however, requires special construction method to avoid scratch damages of the epoxy coating that affects reliability of corrosion protection., ${ }^{3,4)}$ In America and Europe, standardized high corrosion resistance stainless steel has already been employed in those areas damaged by salt as a method of enhancing the corrosion resistance of the reinforcing bar through its characteristic improvements. ${ }^{5-8)}$ Stainless steel rebars (e.g., type 316LN: $16 \% \mathrm{Cr}-12 \% \mathrm{Ni}-$ $2 \% \mathrm{Mo}-0.2 \% \mathrm{~N})$ have shown very good performance in highly saline environments. ${ }^{9,10)}$ Type $304(18 \% \mathrm{Cr}-8 \% \mathrm{Ni})$ stainless steel rebars used for a concrete pier exposed to a tropical marine environment for 60 years showed little corrosion damage. ${ }^{11)}$ Despite its excellent corrosion resistance, stainless steel has not been widely used, due to the high cost resulting from costly elements such as chromium $(\mathrm{Cr})$ and nickel $(\mathrm{Ni})$, which also require additional manufacturing steps as compared with other general steel manufacturing processes.

However, considering the ever increasing maintenance cost for RC structures, it is desirous to conduct the study on the corrosion resistant reinforcing bars that does not require a life cycle cost. Accordingly, when a low stainless steel rebar containing fewer $\mathrm{Cr}$ and $\mathrm{Ni}$ elements (hereafter referred to as Cr-bearing rebar) is made available, the excessive concrete cover thickness can be reduced and the regulation on the water-to-cement ratio will become less strict, at which time the lifetime of RC structures can be extended by using the highly cost effective anticorrosion steel rebars that remain unaffected by corrosion under corrosive environments.

The objectives of the present study are to clarify the relationship between $\mathrm{Cr}$ content in rebars and the corrosion resistance in simulated concrete pore solutions, and to offer a guideline for the alloy design of corrosion resistant rebars.

\section{Outline of Experiment}

\subsection{Materials}

Eight types of steel with different $\mathrm{Cr}$ contents were immersed in solutions with chlorides simulating the environment within concrete pores (hereafter referred to as simulated concrete pore solutions) to measure their pitting potential and impedance and investigate their corrosion morphology. The simulated concrete pore solutions were pre- 
pared by adding sodium chloride $(\mathrm{NaCl})$ to saturated calcium hydroxide $\left(\mathrm{Ca}(\mathrm{OH})_{2}\right)$ solutions and adjusting the $\mathrm{pH}$ values using hydrochloric acid $(\mathrm{HCl})$. Tests were conducted with four $\mathrm{pH}$ values $(12.5,11,10$, and 9) and three chloride $(\mathrm{NaCl})$ concentrations $(0.271 .07$ and $21.4 \%)$. These $\mathrm{NaCl}$ concentrations correspond to the $\mathrm{Cl}^{-}$concentrations in our research work ${ }^{12)}$ that investigated the corrosion resistance of Cr-bearing steel rebars in concrete with high chloride content. In the research work, the concrete contained chloride ion $\left(0.3,1.2\right.$, and $\left.24 \mathrm{~kg} / \mathrm{m}^{3}\right)$, water $\left(185 \mathrm{~kg} / \mathrm{m}^{3}\right)$, and other stuffs (cement, sand, coarse aggregate, and air entraining agent). $0.27 \%, 1.07 \%$, and $21.4 \% \mathrm{NaCl}$ correspond to the concentration of $0.3,1.2$, and $24 \mathrm{~kg} / \mathrm{m}^{3}$ of $\mathrm{Cl}^{-}$ in $185 \mathrm{~kg} / \mathrm{m}^{3}$ of water, respectively. Also, chemical compositions of steels are given in Table 1. The steels containing $\mathrm{Cr}$ from 0 to $16 \%$ were used to change the corrosion resistance in simulated concrete pore solutions. SD345 steel that is a typical carbon steel rebar and SUS304 steel that is a typical austenitic stainless steel were also used to compare the corrosion resistance to the Cr-bearing steels. All steels were produced from $100 \mathrm{~kg}$ vacuum-melted ingots. These ingots were hot forged and hot drawn at $1100-1150^{\circ} \mathrm{C}$ to $13 \mathrm{~mm} \phi$ wires. These wires except SUS304 steel were annealed at $700^{\circ} \mathrm{C}$ for $2 \mathrm{~h}$. SUS304 wires were annealed at $1100^{\circ} \mathrm{C}$ for $5 \mathrm{~min}$. All wires were pickled to remove surface oxides. The wires of the Cr-bearing steels and SD345 steel had ferritic microstructure. The wire of SUS304 steel had austenitic microstructure. These wires were sliced to $2 \mathrm{~mm}$ thick plates for corrosion test specimens.

\section{Experiment Procedure}

\subsection{Pitting Potential}

The pitting potentials were measured to evaluate the resistance to corrosion initiation. The plate specimens were polished to \#800 finish, degreased with acetone, and coated with silicone sealant excepting the measuring area $(10 \mathrm{~mm}$ in diameter). The pitting potentials in deaerated solutions at $30^{\circ} \mathrm{C}$ were measured using a potentiostat. Specimens were polarized in an anodic direction at a rate of $20 \mathrm{mV} / \mathrm{min}$ after 10 -min immersion in the solutions. Pitting potentials were determined as the noblest potentials at which the anodic current exceeded $100 \mu \mathrm{A}$. A specimen with a less negative pitting potential is therefore less prone to corrosion.

\subsection{Impedance}

The impedance of various steel specimens while being

Table 1. Basic compositions of reinforcing, mass $\%$.

\begin{tabular}{|l|l|l|l|l|l|l|l|l|}
\hline Steel & $\mathrm{C}$ & $\mathrm{Si}$ & $\mathrm{Mn}$ & $\mathrm{P}$ & $\mathrm{S}$ & $\mathrm{Cr}$ & $\mathrm{Ni}$ & $\mathrm{Mo}$ \\
\hline SD345 & 0.2280 & 0.31 & 1.34 & 0.029 & 0.020 & 0.084 & 0.04 & 0.016 \\
\hline $0 \mathrm{Cr}$ & 0.0120 & 0.32 & 0.50 & 0.031 & 0.006 & 0.005 & 0.01 & 0.001 \\
\hline $5 \mathrm{Cr}$ & 0.0150 & 0.28 & 0.53 & 0.027 & 0.006 & 5.020 & 0.01 & 0.001 \\
\hline $9 \mathrm{Cr}$ & 0.0107 & 0.28 & 0.53 & 0.028 & 0.006 & 9.140 & 0.01 & 0.001 \\
\hline $11 \mathrm{Cr}$ & 0.0117 & 0.28 & 0.53 & 0.028 & 0.004 & 11.00 & 0.01 & 0.001 \\
\hline $13 \mathrm{Cr}$ & 0.0117 & 0.28 & 0.53 & 0.028 & 0.004 & 13.05 & 0.01 & 0.002 \\
\hline $16 \mathrm{Cr}$ & 0.0113 & 0.29 & 0.53 & 0.027 & 0.004 & 15.98 & 0.01 & 0.002 \\
\hline SUS304 & 0.0630 & 0.31 & 1.01 & 0.026 & 0.006 & 18.36 & 8.28 & 0.053 \\
\hline
\end{tabular}

subjected to corrosion in the simulated concrete pore solutions was measured to evaluate their rate of corrosion. The impedance, the inverse of which is proportional to the rate of corrosion, allows relative comparison between the rates of steel corrosion in concrete. Specimens with the same shapes and dimensions as those for pitting potential were used for this measurement. The argon-deaerated solutions were adjusted to a $\mathrm{pH}$ value of 10 , temperature of $30^{\circ} \mathrm{C}$ with two levels of $\mathrm{NaCl}$ concentrations $(1.07 \%$ and $21.4 \%$ ). The impedance was measured by keeping a potential nobler than the pitting potential to induce corrosion, while changing the measured frequency from $10 \mathrm{kHz}$ to $10 \mathrm{mHz}$ under potential vibration of $\pm 5 \mathrm{mV}$. The time required for measurement was approximately $6 \mathrm{~min}$.

\subsection{Corrosion Morphology}

The corrosion morphology of steels with a Cr content of $0 \%, 5 \%, 9 \%$, and $16 \%$ and SUS304 steel was observed in a pH 10 solution containing $1.07 \% \mathrm{NaCl}$ after the impedance measurement. The corrosion morphology of $16 \mathrm{Cr}$ and SUS304 steels in a pH 10 solution containing $21.4 \% \mathrm{NaCl}$ was also observed.

\section{Results and Discussion}

\subsection{Pitting Potential}

Pitting potentials of the specimens in simulated concrete pore solutions were measured at various $\mathrm{NaCl}$ concentrations and pH. Fig. 1 shows the effect of $\mathrm{Cr}$ content on the pitting potentials. In the case of $\mathrm{pH} 12.5$ solutions contain-

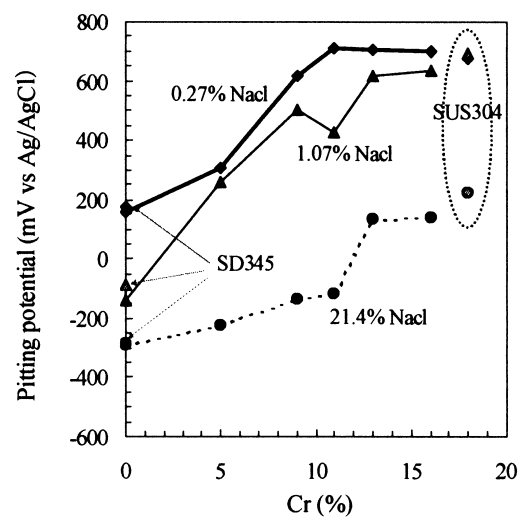

(1) $\mathrm{pH} 12.5$

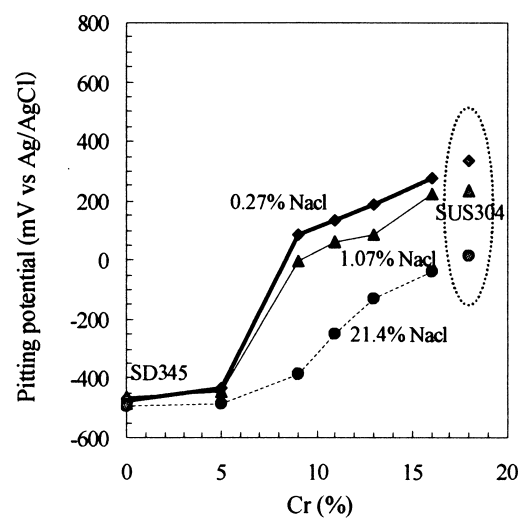

(2) $\mathrm{pH} 10$

Fig. 1. Effect of $\mathrm{Cr}$ content on the pitting potentials of the steels in simulated concrete pore solutions containing $0.27 \%$, $1.07 \%$, and $21.4 \% \mathrm{NaCl}$. 


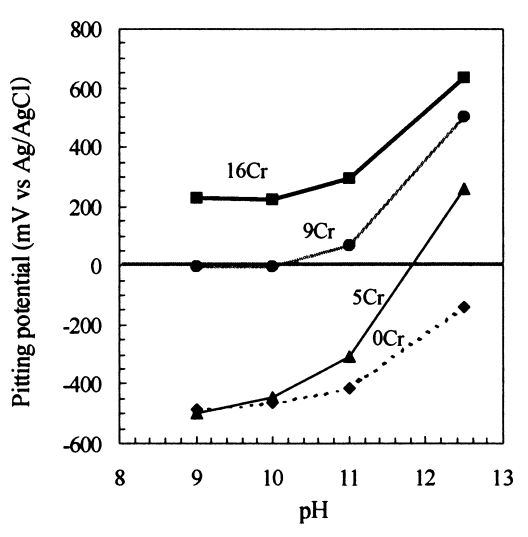

(1) $1.07 \% \mathrm{Nacl}$

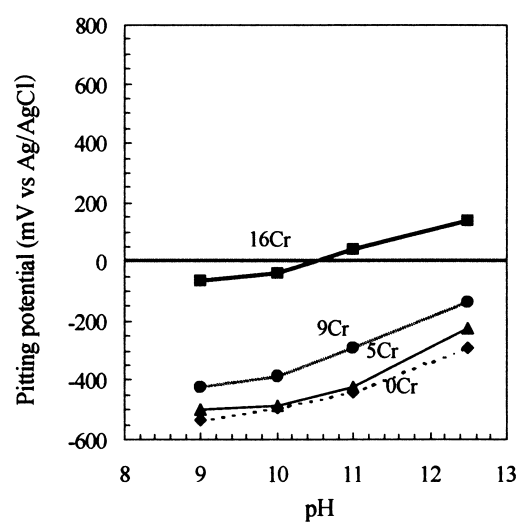

(2) $21.4 \% \mathrm{Nacl}$

Fig. 2. Effect of $\mathrm{pH}$ on the pitting potentials of $0 \mathrm{Cr}, 5 \mathrm{Cr}, 9 \mathrm{Cr}$, and $16 \mathrm{Cr}$ steels in simulated concrete pore solutions.

ing $0.27 \%$ and $1.07 \% \mathrm{NaCl}$, the pitting potential increased considerably with $\mathrm{Cr}$ content up to $11 \%$. The increase of the pitting potentials was comparatively saturated in over $11 \% \mathrm{Cr}$ range. In $\mathrm{pH} 12.5$ solutions containing $21.4 \%$ $\mathrm{NaCl}$, the increase of the pitting potentials with $\mathrm{Cr}$ content was not so large up to $11 \% \mathrm{Cr}$. However, the pitting potential jumped up to a noble direction in the range of more than $13 \% \mathrm{Cr}$. In the case of $\mathrm{pH} 10$ solutions that corresponded to neutralization of concrete, pitting potentials of $0 \% \mathrm{Cr}$ and $5 \% \mathrm{Cr}$ steels were the same level. Pitting potentials increased with $\mathrm{Cr}$ content in over $9 \% \mathrm{Cr}$ range. The corrosion resistance of SD345 steel was almost the same as that of $0 \% \mathrm{Cr}$ steel. The corrosion resistance of SUS304 steel was slightly better than that of $16 \% \mathrm{Cr}$ steel.

Figure 2 shows the effect of $\mathrm{pH}$ values on the pitting potentials in simulated concrete pore solutions containing $1.07 \%$ and $21.4 \% \mathrm{NaCl}$. The bold lines in the graphs represent $0 \mathrm{~V} \mathrm{Ag} / \mathrm{AgCl}(-0.1 \mathrm{~V} \mathrm{CSE})$, i.e., the least negative half-cell potential of Cr-bearing rebars in concrete. As is well known, pitting corrosion begins when the half-cell potential becomes nobler than the pitting potential. The specimens were therefore judged in this study as not being corroded while the pitting potential is nobler than $0 \mathrm{~V}$ $\mathrm{Ag} / \mathrm{AgCl}$. As shown in Fig. 2, the pitting potential becomes more negative as the $\mathrm{pH}$ value decreases. This tendency is more significant in the $1.07 \% \mathrm{NaCl}$ solution, in which a reduction in the $\mathrm{pH}$ value from 12.5 to 11 causes the pitting potentials to become substantially baser. Nevertheless, $\mathrm{pH}$ values lower than 11 led to no marked changes in the pitting potential.

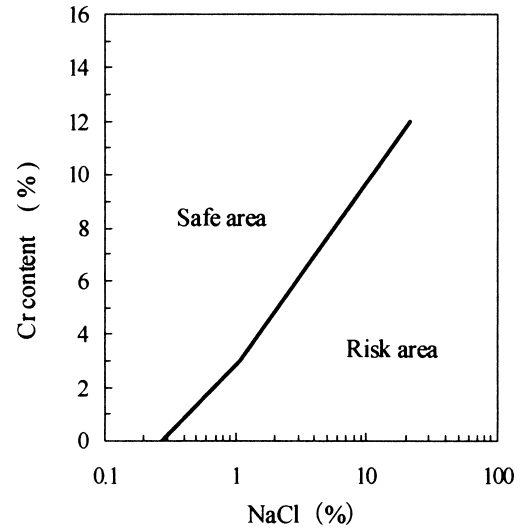

Fig. 3. Guideline map of Cr-bearing corrosion resistant rebars in simulated concrete pore solutions at $\mathrm{pH}$ 12.5.

In the $1.07 \% \mathrm{NaCl}$ solutions, the pitting potential of specimens containing no $\mathrm{Cr}(0 \mathrm{Cr}$ steel) is more negative than $0 \mathrm{~V} \mathrm{Ag} / \mathrm{AgCl}$ even with a $\mathrm{pH}$ value of 12.5 . As for specimens containing $5 \% \mathrm{Cr}(5 \mathrm{Cr}$ steel), the pitting potential is nobler than $0 \mathrm{~V} \mathrm{Ag} / \mathrm{AgCl}$ with a $\mathrm{pH}$ value of 12.5 but becomes more negative as the $\mathrm{pH}$ value decreases to 11 . On the other hand, steels containing $9 \%$ or more $\mathrm{Cr}$ show pitting potentials nobler than $0 \mathrm{~V} \mathrm{Ag} / \mathrm{AgCl}$. In the $21.4 \%$ $\mathrm{NaCl}$ solutions, only $16 \mathrm{Cr}$ shows pitting potentials nobler than the threshold value.

Accordingly, in a solution with a $\mathrm{pH}$ value of 12.5 and $\mathrm{NaCl}$ concentration of $1.07 \%$, steels containing $5 \%$ or more $\mathrm{Cr}$ are considered to resist corrosion. In a solution with a $\mathrm{pH}$ value of 12.5 and $\mathrm{NaCl}$ concentration of $21.4 \%$, corrosion resistance is assured by steel with a $\mathrm{Cr}$ content of at least $16 \%$.

Figure 3 shows the $\mathrm{Cr}$ content related to the $\mathrm{NaCl}$ concentration in simulated concrete pore solutions with a $\mathrm{pH}$ value of 12.5. Since this is a guideline for the risk of corrosion onset, another guideline for service life should also be investigated in terms of the rate of corrosion. However, this figure allows a conservative judgment on the $\mathrm{Cr}$ content of steel reinforcement related to $\mathrm{NaCl}$ concentration, as steel is retained safe unless corrosion occurs. Assuming that uncarbonated concrete is alkaline with a $\mathrm{pH}$ value of $12.5, \mathrm{Cr}$ bearing rebar with a $\mathrm{Cr}$ content of $3 \%$ or more $(5 \mathrm{Cr}$ steel in this paper) is expected to be corrosion-resistant in concrete with a chloride content corresponding to $1.07 \% \mathrm{NaCl}$.

\subsection{Impedance}

In addition to the investigation from the aspect of corrosion onset discussed above, the rate of corrosion should also be investigated to ensure sufficient service life of reinforced concrete structures. As the failure of concrete structures is primarily caused by the volumetric expansion of steel reinforcement due to corrosion products, such structures can attain their required service lives even if corrosion occurs, provided the corrosion rate is sufficiently low.

The corrosion reaction resistance was determined by measuring the impedance of specimens in simulated concrete pore solutions with a $\mathrm{pH}$ value of 10 to compare the rates of corrosion. The measurement of the impedance under the same conditions allows relative comparison between corrosion rates, as the inverse of reaction resistance is proportional to the corrosion rate. Figure $\mathbf{4}$ shows the in- 


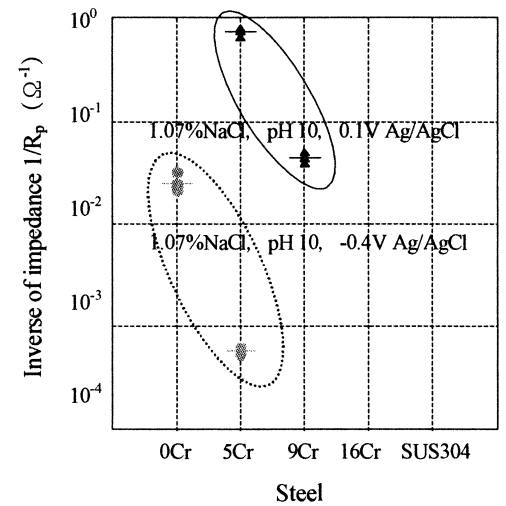

(1) $0 \mathrm{Cr}, 5 \mathrm{Cr}, 9 \mathrm{Cr}$

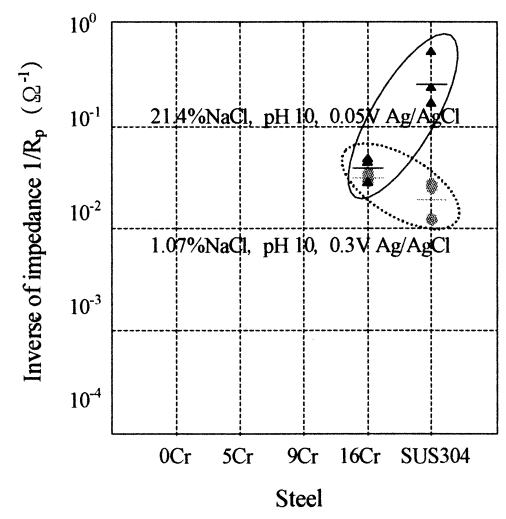

(2) $16 \mathrm{Cr}$, SUS304

Fig. 4. Inverse of impedance of each steel in simulated concrete pore solutions with a $\mathrm{pH}$ value of 10 .

verse of the corrosion reaction resistance, Rp, of each steel. When the $\mathrm{NaCl}$ concentration, $\mathrm{pH}$ value, and applied potential are $1.07 \%, 10$, and $-0.4 \mathrm{~V} \mathrm{Ag} / \mathrm{AgCl}$, respectively, the corrosion rate of $5 \mathrm{Cr}$ steel is approximately $1 / 44$ of that of $0 \mathrm{Cr}$ steel. When these parameters are $1.07 \%, 10$, and $0.1 \mathrm{~V}$ $\mathrm{Ag} / \mathrm{AgCl}$, the corrosion rate of $9 \mathrm{Cr}$ steel is approximately $1 / 17$ of that of $5 \mathrm{Cr}$ steel. In contrast to the similar pitting potentials of $0 \mathrm{Cr}$ and $5 \mathrm{Cr}$ steels with a $\mathrm{pH}$ value of as low as 10 , their corrosion rates significantly differ, with $5 \mathrm{Cr}$ steel showing corrosion resistance superior to $0 \mathrm{Cr}$ steel. When comparing $16 \mathrm{Cr}$ steel and SUS304, the corrosion rate of the former is 1.7 times higher than that of the latter with $1.07 \% \mathrm{NaCl}, \mathrm{pH} 10$, and $0.3 \mathrm{~V} \mathrm{Ag} / \mathrm{AgCl}$. With $21.4 \%$ $\mathrm{NaCl}, \mathrm{pH} 10$, and $0.05 \mathrm{~V} \mathrm{Ag} / \mathrm{AgCl}$, however, the corrosion rate of SUS304 is 6.7 times higher than that of $16 \mathrm{Cr}$ steel. $16 \mathrm{Cr}$ steel can therefore be more resistant to corrosion where the chloride concentration of concrete is extremely high. Figure 5 shows an example of impedance measurement of $9 \mathrm{Cr}$ steel in $\mathrm{pH} 10$ solutions containing $1.07 \%$ $\mathrm{NaCl}$ held at $0.1 \mathrm{~V} \mathrm{Ag} / \mathrm{AgCl}$, which is about $0.1 \mathrm{~V}$ nobler than its pitting potential. This is typical impedance spectra. $\mathrm{Rp}$ was determined as the difference between the maximum impedance measured nearly between 1 and $10 \mathrm{~Hz}$ and the value at $10 \mathrm{kHz}$.

\subsection{Corrosion Morphology}

Figure 6 shows the corrosion morphology of each steel after impedance measurement. Only $16 \mathrm{Cr}$ and SUS304 were investigated in solutions with $\mathrm{pH} 10$ and $21.4 \% \mathrm{NaCl}$, since a $\mathrm{Cr}$ content of at least $16 \%$ was deemed necessary

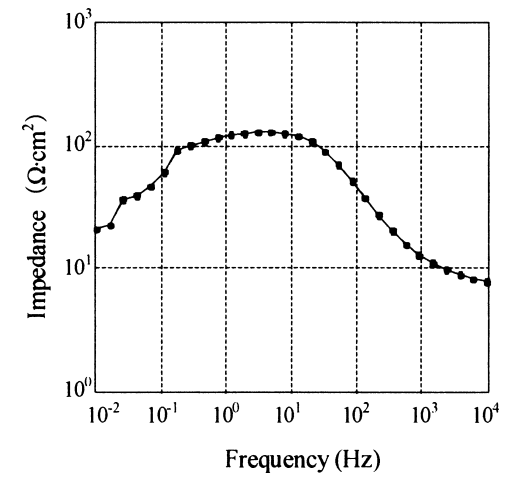

Fig. 5. Example of impedance measurement of $9 \mathrm{Cr}$ steel $[1.07 \%$ $\mathrm{NaCl}, \mathrm{pH} 10,0.1 \mathrm{~V} \mathrm{Ag} / \mathrm{AgCl}]$.

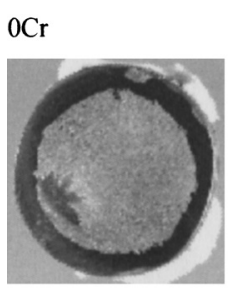

$16 \mathrm{Cr}$

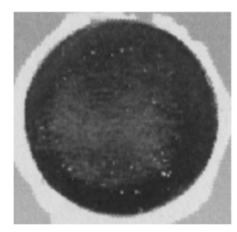

(1) $\mathrm{pH} 10, \mathrm{NaCl} 1.07 \%$

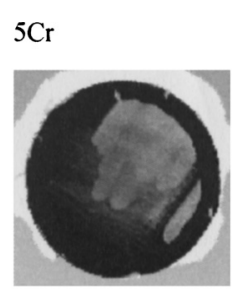

SUS304

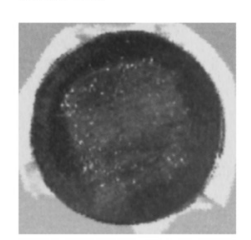

$9 \mathrm{Cr}$
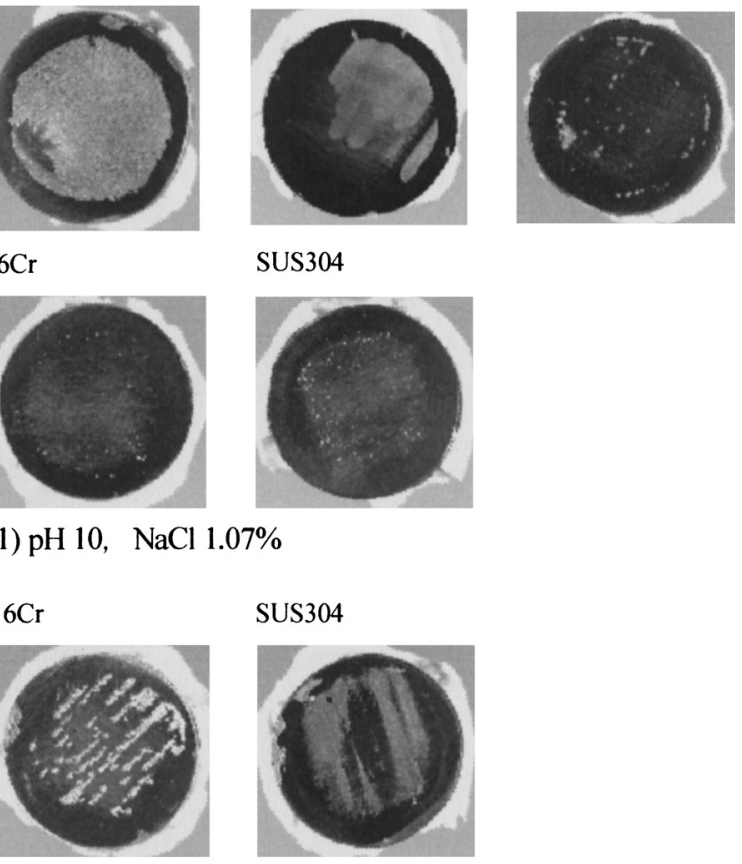

SUS304

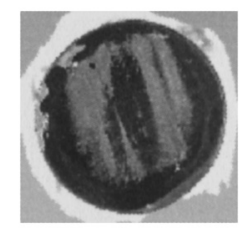

(2) $\mathrm{pH} 10, \quad \mathrm{NaCl} 21.4 \%$

Fig. 6. Corrosion morphology of each steel in simulated concrete pore solutions with a $\mathrm{pH}$ value of 10 .

for resisting such a fierce environment. The figure reveals uniform corrosion of $0 \mathrm{Cr}$ and $5 \mathrm{Cr}$ in the solution with $\mathrm{pH}$ 10 and $\mathrm{NaCl} 1.07 \%$. Though similar pitting potentials were observed for these steels in a solution with $\mathrm{pH} 10$ and $\mathrm{NaCl}$ $1.07 \%$, the corrosion rate of $5 \mathrm{Cr}$ was found lower than that of $0 \mathrm{Cr}$. The low corrosion rate of $5 \mathrm{Cr}$ is observed as the small area of erosion in Fig. 6. For steels with a $\mathrm{Cr}$ content of $9 \%$ or more, corrosion is localized (pitting) in a solution with a $\mathrm{pH}$ value of 10 and $\mathrm{NaCl}$ concentration of $1.07 \%$, with the corroded area of $9 \mathrm{Cr}$ steel being slightly greater than those of $16 \mathrm{Cr}$ steel and SUS304. In a highly corrosive environment with $\mathrm{pH} 10$ and $21.4 \% \mathrm{NaCl}, 16 \mathrm{Cr}$ shows localized corrosion, whereas SUS304 shows uniform corrosion. The lower corrosion rate of $16 \mathrm{Cr}$ steel than SUS304 shown in Fig. 4 is presumably derived from their different modes of corrosion. Table 2 presents the results for pitting potential, impedance, corrosion morphology that were derived form the electrochemical tests. 
Table 2. Corrosion data form the electrochemical tests.

\begin{tabular}{|c|c|c|c|c|c|c|c|c|c|c|c|c|c|c|c|c|}
\hline \multirow[b]{3}{*}{ Steel } & \multicolumn{12}{|c|}{ Pitting Potential (mV vs $\mathrm{Ag} / \mathrm{AgCl}$ ) } & \multirow{2}{*}{\multicolumn{2}{|c|}{ 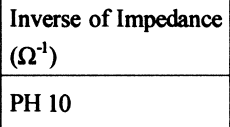 }} & \multirow{2}{*}{\multicolumn{2}{|c|}{ 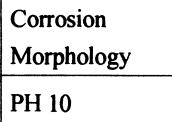 }} \\
\hline & \multicolumn{3}{|c|}{ PH 9} & \multicolumn{3}{|c|}{ PH 10} & \multicolumn{3}{|c|}{ PH 11} & \multicolumn{3}{|c|}{ PH 12.5} & & & & \\
\hline & 0.27 & 1.07 & 21.4 & 0.27 & 1.07 & 21.4 & 0.27 & 1.07 & 21.4 & 0.27 & 1.07 & 21.4 & 1.07 & 21.4 & 1.07 & 21.4 \\
\hline SD345 & -450 & -482 & -568 & -469 & -487 & -493 & -391 & -384 & -464 & 176 & -86 & -284 & - & - & - & - \\
\hline $0 \mathrm{Cr}$ & -467 & -487 & -533 & -474 & -465 & -495 & -408 & -413 & -438 & 155 & -141 & -292 & $0.026(0.1 \mathrm{~V})$ & - & UC & - \\
\hline \multirow{2}{*}{$5 \mathrm{Cr}$} & \multirow{2}{*}{-431} & \multirow{2}{*}{-500} & \multirow{2}{*}{-499} & \multirow{2}{*}{-432} & \multirow{2}{*}{-448} & \multirow{2}{*}{-489} & \multirow{2}{*}{-309} & \multirow{2}{*}{-309} & \multirow{2}{*}{-421} & \multirow{2}{*}{308} & \multirow{2}{*}{255} & \multirow{2}{*}{-223} & $0.001(0.1 \mathrm{~V})$ & \multirow{2}{*}{ - } & \multirow{2}{*}{ UC } & \multirow{2}{*}{-} \\
\hline & & & & & & & & & & & & & $0.746(0.4 \mathrm{~V})$ & & & \\
\hline $9 \mathrm{Cr}$ & 59 & -3 & -424 & 84 & -4 & -386 & 129 & 70 & -291 & 614 & 504 & -138 & $0.044(0.4 \mathrm{~V})$ & - & PC & - \\
\hline $11 \mathrm{Cr}$ & 137 & 88 & -227 & 131 & 64 & -246 & 170 & 126 & -155 & 709 & 426 & -115 & - & - & - & - \\
\hline $13 \mathrm{Cr}$ & 144 & 98 & -158 & 189 & 83 & -127 & 227 & 188 & -197 & 706 & 614 & 130 & - & - & - & - \\
\hline $16 \mathrm{Cr}$ & 264 & 226 & -61 & 277 & 225 & -41 & 307 & 292 & 41 & 697 & 636 & 140 & 0.032 & 0.040 & PC & PC \\
\hline SUS304 & 276 & 229 & -58 & 234 & 234 & 13 & 351 & 268 & 53 & 677 & 690 & 225 & 0.021 & 0.308 & PC & UC \\
\hline
\end{tabular}

UC : Uniform Corrosion, PC : Pitting Corrosion

\section{Conclusions}

For the purpose of developing Cr-bearing rebars that can be used under corrosive environments, experiments were conducted on the corrosion resistance of Cr-bearing rebars in simulated concrete pore solutions.

The following was obtained from these experiments:

(1) The corrosion resistance of steels in simulated concrete pore solutions increased as the $\mathrm{Cr}$ content increased.

(2) The pitting potential of steels became more negative as the chloride concentration in the simulated concrete pore solution increased and as the $\mathrm{pH}$ value of the solution decreased.

(3) In simulated concrete pore solutions with an $\mathrm{NaCl}$ concentration of $1.07 \%$, steel specimens with a $\mathrm{Cr}$ content of $5 \%$ or more and $9 \%$ or more showed resistance to corrosion under $\mathrm{pH}$ values of 12.5 and 10 , respectively.

(4) In a simulated concrete pore solution with a $\mathrm{pH}$ value of 10 and $\mathrm{NaCl}$ concentration of $21.4 \%$, steel specimens with a $\mathrm{Cr}$ content of $16 \%$ showed resistance to corrosion.

\section{Acknowledgements}

This work is part of a study supported by JFE Steel Cor- poration. It is also supported by the Sustainable Building Research Center of Hanyang University, which was supported by the SRC/ERC program of MOST (Grant \# R112005-056-01003-0).

\section{REFERENCES}

1) H. S. Lee, T. Kage, T. Noguchi and F. Tomosawa: Cem. Concr. Res., 33 (2003), 563.

2) K. Okada, K. Kobayashi and T. Miyagawa: ACI Mater. J., 85 (1988), 134.

3) R. A. Treece and J. O. Jirsa: ACI Mater. J., 86 (1989), 167.

4) T. Miura, H. Itabashi and I. Iwaki: ACI Mater. J., 94 (1997), 267.

5) Rasheeduzzafar, F. H. Dakhil, M. A. Bader and M. M. Khan: $A C I$ Mater. J., 89 (1992), 439.

6) G. Ping, S. Elliott, J. J. Beaudoin and B. Arsenault: Cem. Concr. Res., 26 (1996), 1151.

7) S. Erdogdu, T. W. Bremner and I. L. Kondratova: Cem. Concr. Res., 31 (2001), 861.

8) B. G. Callaghan: Corros. Sci., 35 (1993), 1535.

9) F. N. Smith and M. Tullmin: Mater. Perform., 38 (1999), 72.

10) S. Rostam: Mater. Corros., 54 (2003), 369.

11) P. C. Borges, O. T. Rincon, E. I. Moreno, A. A. Torres-Acosta, M. Martinez-Madrid and A. Knudsen: Mater. Perform., 41 (2002), 50.

12) S. H. Tae, T. Noguchi, T. Ujiro and O. Furukimi: 4th Int. Conf. of Concrete under Severe Conditions of Environment and Loading (Consec04), Vol. 1, ed. by B. H. Oh et al., Seoul National University, Seoul, (2004), 303. 